June 2017

\title{
Classification Methods in Context at Theological Libraries: A Case Study
}

Chloe G. Noland

San Jose State University, chloegnoland@gmail.com

Follow this and additional works at: https://scholarworks.sjsu.edu/ischoolsrj

Part of the Cataloging and Metadata Commons, Collection Development and Management Commons, Information Literacy Commons, Scholarly Communication Commons, and the Scholarly Publishing Commons

\section{Acknowledgements}

The author would like to thank Lisa Silverman, Director of the Burton Sperber Jewish Community Library, and Paul Miller, Director of the Bel and Jack M. Ostrow Library, for their support and insight into this study. Additional thanks goes to SJSU iSchool faculty member Dr. Mary Bolin, whose seminar on contemporary metadata practices inspired this project.

\section{Recommended Citation}

Noland, C. G. (2017). Classification Methods in Context at Theological Libraries: A Case Study. School of Information Student Research Journal, 7(1). https://doi.org/10.31979/2575-2499.070103 Retrieved from https://scholarworks.sjsu.edu/ischoolsrj/vol7/iss1/3

This article is brought to you by the open access Journals at SJSU ScholarWorks. It has been accepted for inclusion in School of Information Student Research Journal by an authorized administrator of SJSU ScholarWorks. For more information, please contact scholarworks@sjsu.edu. 


\title{
Classification Methods in Context at Theological Libraries: A Case Study
}

\begin{abstract}
This case study explores issues of interoperability and shared collection management between two libraries - one community and one academic - located within the American Jewish University (AJU). AJU's choice to use two separate classification systems, Library of Congress and Elazar, respectively, provides a necessary separation of academic and religious context, but limits record access between the two collections. Specifically, this study aims to answer the following core research question: is consolidation into one classification scheme both a realistic and helpful solution for increased interoperability? Examining the history, patron needs, and principles of arrangement in both systems provided further insights regarding shared or coexisting collections between libraries that fulfill more than one role. Suggestions for further research are considered, as they relate to theological collections as well as other context-dependent classification systems.
\end{abstract}

\section{Keywords}

theological libraries, academic libraries, Judaic libraries, classification, context, interoperability, knowledge management infrastructure

\section{Acknowledgements}

The author would like to thank Lisa Silverman, Director of the Burton Sperber Jewish Community Library, and Paul Miller, Director of the Bel and Jack M. Ostrow Library, for their support and insight into this study. Additional thanks goes to SJSU iSchool faculty member Dr. Mary Bolin, whose seminar on contemporary metadata practices inspired this project.

\section{About Author}

Chloe Noland is currently working on completing her MLIS in the iSchool program at SJSU, and gaining experience as a library assistant in Los Angeles, CA. Her interests include preservation management, cataloging and metadata practices, literary journalism, and library taxonomy. When she is not working or studying, she enjoys running, playing pool, and watching horror movies. 
The decisions that lead to best practices in library collection maintenance, arrangement, and interoperability design are remarkably complex. The information professional charged with such decisions must make considerations that often do not inform one another. For example, patron needs are a separate issue from budget constraints, as is adherence to principles of traditional classification structure in an increasingly sophisticated digital landscape. Design of interoperability standards with similar or coexisting collections is also a key component of easy record access and retrieval.

These standardizing issues are further compounded in libraries that fulfill more than one role, such as academic libraries at theological universities. Under the umbrella of a religious institution, the library functions as both a broad, educational resource and a specialized, theological collection for its community of students and researchers. As collections serve multiple roles, the fixed layout of their knowledge categorization is simultaneously affected.

This study compares two libraries operating within American Jewish University (AJU). Both collections utilize a separate classification system and staff, but share resources such as duplicate records, shelf space, and integrated library software (ILS). Consolidation into one classification system provides a potential opportunity to increase access to records and usability for both patrons and staff. However, such an undertaking would require extensive time as well as an overhaul of taxonomical structure, and is perhaps unrealistic. Consideration must be given to the libraries' separate missions, patron needs, and resource constraints. In addition, the question of bibliographic context, whether it is rooted in academia or in Judaism itself, is an ongoing debate.

Examining the history, user needs, and principles of arrangement in both libraries can illuminate potential areas of increased interoperability between the two collections. Specifically, this study aims to determine the efficacy of consolidation into one scheme, and explore whether this is a realistic solution for improving interoperability, record retrieval, and access between the two libraries at AJU. In order to achieve this, a history of the two collections and summaries of their classification systems are discussed. This is followed by a literature review focusing on theological issues in classification, and a simple content analysis performed on five records shared by both of AJU's libraries. A conclusion as to whether or not consolidation is a realistic solution, with suggestions for further research, is then determined.

\section{History and Background}

\section{A Tale of Two Libraries}

Filtering education through the lens of theology creates a unique information setting; one such setting can be examined at the two libraries located at the American Jewish University in Los Angeles, California. This Judaic university has a long history of merging programs and practices. Originally founded in 1947 as the University of Judaism, AJU merged with the Brandeis-Bardin Institute in 2007 and connected two campuses: the Brandeis-Bardin campus in Simi Valley and the Familian Campus in Bel Air (AJU, 2017). The latter campus is home to two libraries. The Ostrow Library is the university's main academic and scholarly 
library, and the newly opened Burton Sperber Community Library houses a complementary Judaic collection. The Community Library aims to serve the greater Los Angeles population as well as the research and recreational needs of AJU's faculty and students.

The Ostrow Library seeks to meet the needs of AJU's faculty and students, in addition to those of scholars of Jewish civilization and culture unaffiliated with the university. In addition to biblical, historical, and philosophical resources, it houses 110,000 print volumes, including Hebrew and Yiddish texts. Its Lowy-Winkler Family Rare Book Center contains 4,000 Judaic bibles dating back to the $16^{\text {th }}$ century (AJU, 2017). Furthermore, Ostrow Library's extensive collection of published dissertations encompasses a wide variety of Jewish subjects, its microfilm collection contains manuscripts from the Jewish Theological Seminary, and its archives hold many Israeli newspapers from the turn of the $20^{\text {th }}$ century (AJU, 2017). The Ostrow Library is also part of a larger consortium of Los Angeles-based university libraries, enabling it to offer additional resources to students across the city and state through the Worldcat database and interlibrary loan program.

The Sperber Community Library, in contrast, is a product of the merger between the former Peter M. Kahn Jewish Community Library of Los Angeles and the Sinai Temple Blumenthal Library. While its collection of about 11,000 items is significantly smaller than the Ostrow Library, its fiction and juvenile sections focus specifically on Judaic folklore, ritual practice, and holidays. This makes idle browsing for children and adults effortless, as well as subject-friendly when parents quickly need information on a particular event or detail of a ritual. Acquisitions focus on contemporary titles, and the collection offers new and popular selections of Jewish-oriented reading and research. Additionally, the Sperber "strives to become a community focal point for Jewish intellectual and cultural life in Los Angeles by offering informative and relevant programming for everyone" (Sperber Community Library, 2017). Types of programming include monthly book and film clubs, genealogy-based research sessions, author panels, and family-friendly story-time and craft events.

These two library collections contrast and complement each other, but also present a challenge in interoperability. Consolidating both collections into a unified classification scheme could increase simplicity of access for patrons and staff, minimize duplicate catalog records, and eliminate the need for staff training on two distinct systems. Consolidation could therefore increase many efficiencies, but whether mass reorganization would benefit or hinder information retrieval overall for the AJU libraries requires further discussion of their classification schemes in context. The following section is a detailed explanation of both these systems, and their specific contribution to organization of Judaic materials.

\section{Elazar: A Classification System for Libraries of Judaica}

In 1950, Daniel Elazar, a Jewish librarian, developed the Judaic library classification system most commonly referred to as the Elazar System or Elazar Scheme. While organizing the 10,000-volume library at the United Hebrew Schools (UHS) in Detroit, Michigan, Elazar realized there was a need for a classification schema based on Judaic terminology, history and practice. Elazar 
noted that the commonly used classification schemes, Library of Congress Classification (LCC) and the Dewey Decimal System (DDC), "[incorporated] the Bible, Judaism, and Israel into a general, non-Jewish world of knowledge without relating Jewish and Jewish-Oriented subjects to one another" (Elazar, 2008, p. 16).

The Elazar System imitates DDC's first summary faceted structure by using the ten main classes numbered 000-900. However, each class corresponds specifically to Jewish texts, history, critical thinking, and overall pedagogy. Elazar aimed to improve browsing capability by organizing the collection in a linear, historical order: Biblical Studies in 001 were followed by Classical Judaica (Laws and Myths) in 100, Observance and Practice in 200, Education in 300, Languages and Science in 400, Literature in 500, Society and the Arts in 600, History, Geography and Biography in 700, Israel and Zionism in 800, and General Works in 900 (Elazar, 2008). Elazar worked with his brother, David, to write and test the first drafts of the system in the 1950s; they circulated the system among other libraries and Jewish catalogers in 1962 for critique. Initial reactions were unenthusiastic, and it was not until 1968 that the first edition was published by Wayne State University Press (Schopert, 2014). Elazar himself worked as a Science Librarian at Wayne State University (WSU), which utilized the Elazar scheme in its manuscript form prior to publication, essentially as an elaborative tool for Judaic materials within their DDC system. However, its use was ultimately discontinued when the university switched to LCC in 1964 (D. Breneau, personal communication, April 26, 2017). The third and most recent edition of Elazar was published in 1997, by Jason Aronson, Inc.

The fundamental advantage of this system is that its intuitive logic makes it much more user-friendly, most notably for Jewish rabbis and scholars. Additionally, organizing a juvenile section with these classes makes it fairly easy for parents to find appropriate texts with which to educate and familiarize their children with Jewish traditions. In collections organized with LCC or DDC, Jewish texts wound up scattered throughout a library, with no discernible association with each other. As Schopert (2014) notes, "at the time Elazar was developed, DDC had one assigned number for Judaism (296). Other books related to Judaism were found in various locations throughout a library" (p. 427). Despite this intuitive layout, the main disadvantage of Elazar is its specificity and lack of standardizing capability. In fact, this was the major complaint of Jewish librarians and catalogers during the system's initial critique. Reviewers did not see it as functional within the larger scope of an academic collection, whose patrons included non-Jewish researchers or needed documents unrelated to Jewish culture (Elazar, 2008).

For these reasons, Elazar has most largely been implemented in synagogue libraries, or special collections that are specifically devoted to the Talmud and other rabbinical literature. The Sperber Community Library utilizes this classification scheme, undoubtedly due to the fact that its resources largely draws from children's books in Jewish temple school libraries, and were previously cataloged in this fashion. 


\section{Library of Congress Classification (LCC)}

Since its implementation at the Library of Congress (LC) at the turn of the $20^{\text {th }}$ century, the Library of Congress Classification system (LCC) has been used in almost every research and academic library in the United States. Herbert Putnam, the Librarian of Congress from 1899 to 1939, fashioned the scheme for the LC collection after DDC, the Cutter Expansive Classification, and his own Putnam Classification System, which he developed while working as head librarian at the Minneapolis Athenaeum (Library of Congress, 2014).

LCC is semi-hierarchical and is organized by letters of the alphabet instead of by numbers. Its 21 basic classes each correspond to a letter of the alphabet (A is General Works, B is Philosophy, C is Auxiliary Sciences, etc.), and each class can be further subdivided by adding an additional letter. For example, "class N, Art, has subclasses NA, Architecture, NB, Sculpture, ND, Painting... each subclass includes a loosely hierarchical arrangement of the topics pertinent to the subclass, going from the general to the more specific" (LC, 2014). The topics are represented by either a single number or grouping of numbers and are sometimes extended past the decimal point.

Organizing from broad subject areas to specific topics demonstrates relationships among subjects, just as indenting subtopics under larger topics in an outline does (LC, 2014). For purposes of organizing material in a large, academic setting, this flow of indexing is intended to be relational, cross-referential, and continuous. LC further aids in the development and understanding of related topics with its Library of Congress Subject Headings (LCSH), a controlled vocabulary that assigns keywords, or headings, to specific genres, people, places, events, and time periods.

For purposes of bibliographic control, as well as for searching capabilities in library catalogs, these tools allow a researcher to narrow and widen the search scope. The fact that most academic and research libraries in the United States use LCC as their standard classification system is important to note, as utilization of LCC promotes interoperability through numerous collections, library consortiums, and interlibrary loan programs. The Ostrow Library employs LCC as their classification scheme, largely due to its academic standing and familiarity to patrons.

\section{Literature Review}

\section{Religious Classification Needs in a Secular World}

Although the professional literature on issues of classification in religious libraries is quite diverse, there is a lack of research specifically comparing interoperability design between Judaic and academic classification in coexisting collections. In most cases, the library in question will adopt one or the other and follow the standard academic path, or the Judaic (or special collection) path. The latter possibility is facilitated by the development of several Judaic classification schemes in addition to Elazar. Schoppert (2014) mentions several alternative schemes used in North America, including the Weine Classification Scheme, the

Abraham Freidus Classification Scheme for the Jewish Division of the New York 
Public Library, the Gershom Scholem Classification Scheme for the Jewish National and University Library, and the Leikind Classification Scheme (p. 424).

The dichotomy between standardization and specification in religious classification is equally exemplified in the many Christian-based schemes developed throughout the world. Most notable is the Union Classification system, developed by Julia Pettee at the turn of the 20th century. This system was a staple of church libraries well into the 1970s, when the introduction of library automation systems trumped specification with access and ease of use (Butler, 2013). Pette's belief in context as well as standardization provoked a desire for a system that would both integrate "an infinite number of correlated parts" as well as avoid putting theological students into "a glass cage separate from the world" (Butler, 2013, p. 22). Pettee's project took over fifteen years to complete but ultimately failed to consolidate all theological collections on a universal level, and many of its nuances reflect the same desire for specification as Elazar's scheme.

The challenges of dealing with interoperable design and mixed collection policies is similarly exemplified in a study of Eastern religions. Idrees (2012) explored the problems with organizing Islamic materials by interviewing information professionals handling these types of collections. When discussing the problem of adopting "incoherent, inconsistent, and non-uniform practices" (Idrees, 2012, p. 172) in attempts to classify Islamic material along with broader subjects, library staff chiefly advocated for developing a new, independent classification system for such materials. Another suggestion was to adjust and expand standard classification systems as needed in order to reflect the local requirements of institutions (Idrees, 2012, p. 177).

Many libraries based in theological settings but limited by traditional classification systems choose to adjust their system to better serve their patrons. Some librarians change the conceptual and physical layout of their collections based on nuances in classification systems that hinder access for their patrons. Woodward (2011) worked in an Indian seminary library where, for the majority of patrons, English was their third or fourth language, and they could not make sense of the DDC call numbers. Woodward rearranged the classes into broad categories, in an effort to make information accessible:

I found it particularly useful when dealing with the Counseling classification, where I had subjects like counseling, sex, marriage, sickness (read alcoholism/abortion), children, families, growing old and coping with death. I gave Counseling the main number, every other subject became point 1 , point 2 , point 3 , etc, and they all went on the same set of shelves (p. 115).

While this hybrid solution seems to work well in some libraries, it is merely a localized solution, which fails to address a more systemic problem. Religious collections lack accurate vocabulary and classification to satisfy specificity of topic while still maintaining order and consistency in workflow and patron access. As Idrees (2012) notes, "having multiple systems of classification has its own repercussions. It affects uniformity of the system and complicates training of both staff and library users" (p. 178). The only solution suggested thus far has been the call for implementation of a new system that both supports 
theological order and does not conflict with notations of standard systems (Idrees, 2012, p. 179). However, this would require extensive collaboration between the institutions that manage standard schemes (such as LCC and DDC) and the religious librarians that manage theological collections (Idrees, 2012, p. 180).

Putting aside the problem of mixed collection policies, issues of arrangement and consolidation of records have never been an easy task in Judaic libraries. Drobnicki (2014) discusses the difficulty in deciding whether to classify Holocaust denial literature in the same section as traditional history of Judaism: "Should they be classified with a call number that places them physically next to the books that are generally accepted to be standard, accurate histories of the Holocaust?" (p. 56). In this instance, context is part of the discussion, and cataloging librarians must use their own judgment and personal knowledge of their community to determine the best fit. The often subjective methods of classifying Judaic materials is further complicated by a library's distinct programs and missions. Stahl and Kushner (2014) point out the issue of conflicting goals in Judaic libraries that have simultaneously related but unique missions. Specifically, the authors question whether a collection development policy structured for a research library can also be used for a synagogue or seminary collection (Stahl \& Kushner, 2014, p. 18). Considerations such as these illuminate the problems in classification decisions and in the differing administrative structures of theological libraries.

\section{LCC and Elazar in Theological and Academic Settings}

The implications of implementing LCC in a theological setting, or conversely Elazar in an academic setting, bring with them their own unique problems. As previously stated, LCC is not organized from or within a Judaic context; it is organized within the context of a secular, academic worldview. Elazar, on the other hand, was developed specifically by Jewish librarians to be used for easier retrieval of Judaic materials. As such, it is ideally suited to either a special collection or community library, rather than a broad, academic collection.

From an outsider's perspective, LCC's lack of specificity in organizing Jewish content is not necessarily viewed as a lack of support or interest in the Judaic way of life, but rather as part of the general problem of identifying specific topics within broad, standardized systems. As early as 1995, LCC made additions to their published schedules to include sub-classifications pertaining to Judaic philosophy, biblical studies, general history, folklore, law, agriculture, arts and literature, and more (Ruderman, 2000). Specifically, the incorporation of Hasidism as a subtopic allowed librarians to isolate works about this particular Jewish sect by region and country, as well as to classify separate movements within the sect itself (Ruderman, 2000, p. 31).

Despite these improvements, authors such as Conners (2009) bring to light the issues of inherent bias in the vocabulary and enumerative structure of LCC, and suggest that terminology needs updating to allow for specific as well as broad searching contexts. Specifically, Conners notes LCSH's lack of specification between the terms Hebrew Bible, Old Testament, and New Testament. This lack of distinction reflects Christian understandings of these holy books, and is often referred to as Christian primacy. 
Not only is the actual language of the term 'Old Testament' problematic because of its Christian origin, but the bias pervades the cross references as well. Library of Congress's authority file continues to lack a see reference from 'Jewish Bible' to the authorized term Bible. O.T., and other see references such as 'Five books of Moses' were not included until the mid-1980s. Cross references from variant names are essential for the uniform title to work in directing searchers to the proper heading (Conners, 2009, p. 2).

Further examination of the conceptual structure of LCC's arrangement of Jewish topics reveals the categorization of Jews as "a narrower term of Christianity" (Schoppert, 2014, p. 427). This bias is additionally evident in other subject headings lists, such as the Sears list, often used as a companion to LCSH in small collections. Referring to inadequacies in subject cataloging concerning the Sears list, Elsesser notes that "librarians have a responsibility to avoid employing labels which connote or imply a judgment...as an ethical matter, this seems an unassailable position; as a practical matter, it can help avoid inconsistencies and cataloging trauma" (as cited in Rofofsky, 2011, p. 116).

Religious persons and organizations are not the only victims of bias in classifications systems; there is evidence of prejudice against specific races, genders, and learning styles. As Tewell (2016) points out, "white supremacy inherent in classifications system[s] is thrown into sharp relief when a student asks... whether they need to search specifically for 'white' in the subject headings. The answer is no, pointing to an assumption of universal whiteness" (p. 293).

Issues of gender bias have been illuminated by researchers such as Olson (2002), who examined the headings and call numbers of specific books within the context of their classification systems. Olson examined eleven books that "combine[d] a feminist perspective with attention to women identifying with...African American women, Chicanos, lesbians, Asian American women, working class women, Jewish women, [and] North American aboriginal women" (p. 184). During analysis of these book's assigned subject headings and call numbers, Olson found that the "systems [in use] lack the ability to express the diversity of such book's subject matter" (as cited in Mai, 2016, p. 328), and so their actual subject matter was disregarded and marginalized within the broader context of the system. Remarking on Olson's findings, Mai (2016) concluded that even neutrality on behalf of the scheme, in order to apply to the widest audience possible, can become a form of inadvertent bias (p. 327).

Interestingly, the authors of Elazar acknowledge a major difficulty in their system, as "material with no specifically Jewish content has to be classified under another system, thus creating a situation where the user...has to learn two systems" (Elazar, 2008, p. 21). Despite this, Elazar's supporters contend that the advantages of having a system devoted specifically to Judaic thought and materials outweigh the difficulty of having to separately catalog general works. Inclusion of categories for some broader materials, such as Comparative Religion, General Education, Psychology, the Middle East, General Reference Works, and Library Science helps to mitigate the system's difficulties. 


\section{Methodology}

In order to better understand the principles of organization in LCC and Elazar and gain insight into potential areas of improved interoperability design between two collections, five records for items present in both the Ostrow and Sperber libraries were chosen for a simple content analysis. Provided in the analysis are the record title, author, LCC call number, Elazar call number, and the accompanying LC Subject Headings, as provided by the shared Worldcat database. Records were chosen randomly from five subjects in order to represent a broad spectrum of arranging principles in both systems.

Due to the subjective aspect of Judaic material arrangement, this analysis focuses solely on advantages and disadvantages as they relate to the educational and theological needs of AJU's patrons. In this way, the author hopes to make clear which system better represents both contexts in their knowledge infrastructure and where context is lacking in each. This evaluation will illuminate whether consolidation is a realistic and helpful solution and, if so, which system is the better choice for consolidation of both collections. It should be understood that the small sample size of this dataset is not adequate for making broad determinations about the patterns of inconsistency in theological collections. These records serve as a starting point for further research and will only be discussed in the context of AJU's library system.

\section{Analysis and Discussion}

\begin{tabular}{|c|c|c|c|c|}
\hline $\begin{array}{l}\text { Table } 1 \\
\text { Comparison of } L C\end{array}$ & and Elazar classi & cation of texts & biblica & nyths and laws \\
\hline Title & Author & LCC Call \# & $\begin{array}{l}\text { Elazar } \\
\text { Call \# }\end{array}$ & $\begin{array}{l}\text { LCSH } \\
\text { Entries }\end{array}$ \\
\hline \multirow{6}{*}{$\begin{array}{l}\text { The book of } \\
\text { legends = Sefer } \\
\text { haggadah: } \\
\text { Legends from the } \\
\text { Talmud and } \\
\text { Midrash }\end{array}$} & \multirow{6}{*}{$\begin{array}{l}\text { Bialik, H. N. } \\
\text { (ed.), Rawnitzki, } \\
\text { Y. H. (ed.), } \\
\text { Braude W. G. } \\
\text { (trans.) }\end{array}$} & \multirow{6}{*}{$\begin{array}{l}\text { BM516.B52 } \\
\text { E5 } 1992\end{array}$} & \multirow{6}{*}{$\begin{array}{l}140.6 \\
\mathrm{Bia}\end{array}$} & $\begin{array}{l}\text { Aggada -- } \\
\text { Translations in } \\
\text { English. }\end{array}$ \\
\hline & & & & $\begin{array}{l}\text { Midrash -- } \\
\text { Translations in } \\
\text { English. }\end{array}$ \\
\hline & & & & $\begin{array}{l}\text { Jewish } \\
\text { legends. }\end{array}$ \\
\hline & & & & $\begin{array}{l}\text { Legends, } \\
\text { Jewish. }\end{array}$ \\
\hline & & & & Aggadah. \\
\hline & & & & Midrash. \\
\hline
\end{tabular}

As both a Judaic and an academic library, the majority of Ostrow's collection is comprised of items with LCC's BM call number (Religion -Judaism). The Book of Legends = Sefer Haggadah: Legends from the Talmud and 
Midrash, edited by Hayyim N. Bialik and Yehoshoua H. Ravnitzky (see Table 1), is placed by LCC in BM516, which denotes texts on the Midrash, and is further delineated by .B52, for criticisms and commentaries. The Midrash is a supplemental commentary to the Hebrew Bible that consists of rabbinical sermons, homilies, and other stories. Elazar's structure, in contrast, already assumes a Judaic context, so they place this text in 100 (Classical Judaica: Halakhah and Midrash), which is specifically devoted to study of Judaic texts on law and myth; this class is subdivided into several categories. 140.6 (Aggadah Research and Criticism of) is specifically devoted to a particular commentary within the Midrash that discusses the non-legal portions of the Hebrew Bible, mainly through philosophical or mystical discourse. The LCSH entries contextualize the record a step further, however, by noting that this book is a translation, and including useful, searchable headings, such as "Jewish legends." Consequently, although the Elazar system requires fewer steps to contextualize this work, LCC provides more access points via its additional subject headings.

\begin{tabular}{|c|c|c|c|c|}
\hline \multicolumn{5}{|c|}{$\begin{array}{l}\text { Table } 2 \\
\text { Comparison of LCC and Elazar classification of biographical texts }\end{array}$} \\
\hline Title & Author & $\begin{array}{l}\text { LCC Call } \\
\#\end{array}$ & $\begin{array}{l}\text { Elazar } \\
\text { Call \# }\end{array}$ & LCSH Entries \\
\hline \multirow{7}{*}{$\begin{array}{l}\text { Unorthodox: The } \\
\text { scandalous } \\
\text { rejection of my } \\
\text { Hasidic roots }\end{array}$} & \multirow{7}{*}{$\begin{array}{l}\text { Feldmna, } \\
\text { D. }\end{array}$} & \multirow{7}{*}{$\begin{array}{l}\text { F128.9.J5 } \\
\text { F525 } 2012\end{array}$} & \multirow{7}{*}{$799 \mathrm{Fel}$} & $\begin{array}{l}\text { Feldman, Deborah, -- } \\
\text { 1986- }\end{array}$ \\
\hline & & & & $\begin{array}{l}\text { New York (N.Y.) -- } \\
\text { Religion. }\end{array}$ \\
\hline & & & & $\begin{array}{l}\text { Satmar Hasidism -- } \\
\text { New York (State) -- } \\
\text { New York -- } \\
\text { Biography. }\end{array}$ \\
\hline & & & & $\begin{array}{l}\text { Satmar Hasidism -- } \\
\text { New York (State) -- } \\
\text { New York -- Social } \\
\text { conditions. }\end{array}$ \\
\hline & & & & $\begin{array}{l}\text { Williamsburg (New } \\
\text { York, N.Y.) -- } \\
\text { Religion. }\end{array}$ \\
\hline & & & & $\begin{array}{l}\text { Jews -- New York } \\
\text { (N.Y.) -- Biography. }\end{array}$ \\
\hline & & & & $\begin{array}{l}\text { Jews -- New York } \\
\text { (State) -- New York -- } \\
\text { Biography. }\end{array}$ \\
\hline
\end{tabular}

Examining the LC and Elazar call numbers and subject headings ascribed to Unorthodox: The Scandalous Rejection of My Hasidic Roots, by Deborah Feldman (see Table 2) illuminates multiple characteristics of this work, which may not be noted if classification were uniformly consolidated into one system. This record in particular encompasses several different genres and topics; it is a contemporary discourse on Hasidic Judaism, a personal biography, and a 
reference to a specific time period and geographical place. LCC uses that last category to place the work in F128.9, History of the Americas -- United States local history, New York. The LCSH entries further reinforce the geographical element and also suggest placement within Jews, Social conditions, Biography, and Hasidism. In this way, LCC covers multiple aspects of the work. Using Elazar, on the other hand, the cataloger was able to choose among several classes. This is an example of how an information professional incorporates preference and personal judgment, based on patron needs and information-seeking behavior. Although the librarian ultimately decided to place the book in 799 (Biographies -individual), likely for purposes of anticipated best access, it could have also been classified geographically in 774.1 (United States Jewry -- Middle Eastern States -New York). An additional possibility is 213.9 (Hasidism -- Anti-Hasidic writings), although the social and personal message of the book is not quite the right fit for this class. Unorthodox tells the story of a Jewish person realizing the importance of their faith through preliminary rejection of a Hasidic upbringing, which need not necessarily be inferred as anti-Hasidic writing.

\begin{tabular}{|c|c|c|c|c|}
\hline $\begin{array}{l}\text { Table } 3 \\
\text { Comparis }\end{array}$ & $L C C$ ar & Elazar classifi & of fictic & al texts \\
\hline Title & Author & LCC Call \# & $\begin{array}{l}\text { Elazar } \\
\text { Call \# }\end{array}$ & LCSH Entries \\
\hline \multirow{9}{*}{$\begin{array}{l}\text { American } \\
\text { pastoral }\end{array}$} & \multirow{9}{*}{$\begin{array}{l}\text { Roth, } \\
\text { P. }\end{array}$} & \multirow{9}{*}{$\begin{array}{l}\text { PS3568.0855 } \\
\text { A77 } 1997\end{array}$} & \multirow{9}{*}{ Fic Roth } & $\begin{array}{l}\text { United States -- History - } \\
\text { - 1961-1969 -- Fiction. }\end{array}$ \\
\hline & & & & $\begin{array}{l}\text { Jewish businesspeople -- } \\
\text { Fiction. }\end{array}$ \\
\hline & & & & Bombings -- Fiction. \\
\hline & & & & New Jersey -- Fiction. \\
\hline & & & & Bombings. \\
\hline & & & & Fathers and daughters. \\
\hline & & & & Jewish businesspeople. \\
\hline & & & & New Jersey. \\
\hline & & & & United States. \\
\hline
\end{tabular}

Once again, the thematic subjects of American Pastoral (see Table 3), a fictional novel by Jewish author Philip Roth, are covered by LCC through its supplemental subject headings, and the book is appropriately placed in PS3568, American literature -- 1961-2000. Elazar places the book in Fic, Roth, which is appropriate in the context of a community library, where idle browsing by title or author is perhaps more common than in academic settings. However, Elazar inadvertently ignores the deeper themes of the text, while LCC pinpoints them with additional subject headings such as Fathers and daughters and Bombings Fiction. 


\begin{tabular}{|c|c|c|c|c|}
\hline $\begin{array}{l}\text { Table } 4 \\
\text { Comparison of LCC }\end{array}$ & Elazar c & ssification of & ts on glo & ization \\
\hline Title & Author & LCC Call \# & $\begin{array}{l}\text { Elazar } \\
\text { Call \# }\end{array}$ & LCSH Entries \\
\hline \multirow{6}{*}{$\begin{array}{l}\text { The world is flat: A } \\
\text { brief history of the } \\
\text { twenty-first century }\end{array}$} & \multirow{6}{*}{$\begin{array}{l}\text { Friedman, } \\
\text { T.L. }\end{array}$} & \multirow{6}{*}{$\begin{array}{l}\text { HM846.F74 } \\
2005\end{array}$} & \multirow{6}{*}{735 Fri } & $\begin{array}{l}\text { Diffusion of } \\
\text { innovations. }\end{array}$ \\
\hline & & & & $\begin{array}{l}\text { Information } \\
\text { society. }\end{array}$ \\
\hline & & & & $\begin{array}{l}\text { Globalization -- } \\
\text { Social aspects. }\end{array}$ \\
\hline & & & & $\begin{array}{l}\text { Innovations -- } \\
\text { Diffusion. }\end{array}$ \\
\hline & & & & Internet. \\
\hline & & & & New economy. \\
\hline
\end{tabular}

Very often, works by Jewish authors on non-Jewish topics are included in Judaic collections. The World is Flat: A Brief History of the Twenty-first Century, by Thomas L. Friedman (see Table 4) is an example of a secular work on society and globalization by a Jewish author. In LCC, HM846 places the work in Sociology (General) -- Social change. The LCSH entries additionally categorize it within the subjects of innovation, economics, and the Internet. Elazar, conversely, places this book in 735: History, Geography and Biography -- The Contemporary Era (20th Century--). Although the book's themes, as classified by LCC, could very well fit within Elazar's broader category, the latter remains generalized in the Judaic context. The most logical conclusion is that this book probably had a high number of requests, and may have been added to both collections in order to meet patron demand. In this case, simpler classification is acceptable by the Sperber Library in order to better serve their community. However, the contingency in assigning broad terms to records with specific nuances is demonstrated again, in this instance by the specialized scheme.

Arthur Schwartz's Jewish Home Cooking: Yiddish Recipes Revisited, by Arthur Schwartz (see Table 5) illuminates several more detailed distinctions between the two classification systems. A Jewish cookbook of Yiddish recipes is placed by LCC in TX724: Home economics -- Cooking. The accompanying LCSH entries help contextualize the content, ascribing the text to Jews, Jewish Cooking, Social life and customs, and New York (State). The reason for including the geographical subheading is due to the fact that the author is a New Yorker, and includes anecdotal stories about the city within the text. Elazar has its own subtopic within the 600's (Society and the Arts), 699: Cooking and Culinary Arts. 699.2 Regional cooking, refers to Sephardic, Ashkenazic, or Oriental cookery, which is where Yiddish dishes would be included. While other subtopics within 699 distinguish between different types of Jewish cooking, LCC stays broad, and includes the New York subheading as a way of incorporating the author's geographical culture. Due to the fact that Elazar's structure already implies a Jewish cultural context, the call number merely delineates the type of cookbook. 


\begin{tabular}{|c|c|c|c|c|}
\hline $\begin{array}{l}\text { Table } 5 \\
\text { Comparison of } L \\
\text { (cooking) }\end{array}$ & C and Ela & ar classificatior & of texts & n home economics \\
\hline Title & Author & LCC Call \# & $\begin{array}{l}\text { Elazar } \\
\text { Call \# }\end{array}$ & LCSH Entries \\
\hline \multirow{7}{*}{$\begin{array}{l}\text { Arthur Schwartz's } \\
\text { Jewish home } \\
\text { cooking: Yiddish } \\
\text { recipes revisited }\end{array}$} & \multirow{7}{*}{$\begin{array}{l}\text { Schwartz, } \\
\text { A. }\end{array}$} & \multirow{7}{*}{$\begin{array}{l}\text { TX724.S3335 } \\
2008\end{array}$} & \multirow{7}{*}{$\begin{array}{l}699.2 \\
\text { Sch }\end{array}$} & Jewish cooking. \\
\hline & & & & $\begin{array}{l}\text { Jews -- United } \\
\text { States -- Social life } \\
\text { and conditions. }\end{array}$ \\
\hline & & & & $\begin{array}{l}\text { Jews -- New York } \\
\text { (State) -- New } \\
\text { York -- Social life } \\
\text { and customs. }\end{array}$ \\
\hline & & & & Cookery -- Jewish. \\
\hline & & & & $\begin{array}{l}\text { Jews -- Social life } \\
\text { and customs. }\end{array}$ \\
\hline & & & & $\begin{array}{l}\text { New York (State) - } \\
\text { - New York. }\end{array}$ \\
\hline & & & & United States. \\
\hline
\end{tabular}

For purposes of Jewish themes and subjects, and concerns debated within the context of Judaism, Elazar overwhelmingly provides the best specificity. For the needs of education, it is less clear which system is better. LCC provides the more precise classification, as seen with American Pastoral (Table 3), by providing deeper thematic context with nuances of time period, location, and relationships; meanwhile, Elazar merely lumps the book into Fic, Roth. In essence, missing information in one scheme is consistently provided in the other. It is also worth noting that while Elazar implies greater specificity, the user in question must already be familiar with Judaica to benefit from this. LCC, on the other hand, implies less specificity, but its LCSH entries provide enhancement of themes and nuances that Elazar does not state conspicuously. Thus, a patron unfamiliar with Judaica may have an easier time interpreting and accessing theological records via LCC, while Elazar's organization chiefly benefits those already educated in Jewish terms and contexts. In this regard, further study of how theological and academic classification systems impact collection development could prove thought-provoking, particularly towards fulfillment of patron requests.

\section{Conclusion}

This study aimed to explore and provide solutions for increased interoperability design between AJU's academic and community libraries. Reviewing the literature on classification issues in religious collections revealed that the majority of theological libraries take one of three different approaches to categorizing materials: 1) use a standard scheme (e.g., LCC and LCSH), 2) employ a local and/or special scheme, such as Elazar in a Jewish collection, or 3) alter a standard scheme to match local needs. The second and third choices, although manageable in many circumstances, still fail to solve interoperability problems at large. 
The limitations of LCC in a religious environment and of Elazar in an academic environment are evident upon examination. This analysis of library needs and item records reveals that, in the case of AJU, each collection depends on the other to improve its catalog and better serve its community. The fact that both libraries function better in conjunction with the other classification system as reference was an interesting discovery of this study.

Due to this insight, this author believes the division of the two classification systems is indeed a positive consequence of collection disunity. However, understanding the specific use and priorities of each library is vital. The problem arising is how to maintain interoperability between the two libraries, despite the different content and communities. Realistic solutions include increasing transparency on the shared catalog, as well as utilizing a marketing campaign to explain the mission of both libraries. These options would be much less costly and time-consuming than a reclassification process.

A deeper analysis than this study's time constraints and data sample were able to produce is needed in order to make broad determinations about interoperability design between theological and general collections. Future research could include qualitative studies comparing the classification structure of records across several different religious and secular libraries. These studies could examine differing Judaic, Christian, and Islamic schemes as compared against DDC, Colon Classification, Universal Decimal Classification, and other standard schemes. By isolating the records within the context of their classification systems, in-depth comparisons will continue to reveal more about the benefits and disadvantages that these vastly different schemes offer. Additionally, increased understanding of specific materials will help enhance metadata terminology and further determine exactly where and why context is necessary.

\section{References}

American Jewish University. (2017). Ostrow Library homepage. Retrieved from http://library.aju.edu

Butler, R. (2013). The rise and fall of Union Classification. Theological Librarianship, 6(1), p. 21-28.

Conners, D. (2009). A 'mind-boggling' implication: the Hebrew Bible, the Old Testament, and the definition of a work. Judaica Librarianship, 15, p. 112.

Drobnicki, J. (2014). Holocaust denial literature twenty years later: A follow-up investigation of public librarians' attitudes regarding acquisition and access. Judaica Librarianship 18(1), p. 54-87.

Elazar, D. H. (2008). The making of a classification scheme for libraries of Judaica. Judaica Librarianship, 14, p. 15-25.

Idrees, H. (2012). Library classification systems and organization of Islamic knowledge: Current global scenario and optimal solution. Library Resources \& Technical Services, 56(3), p. 171-182. 
Library of Congress. (2014). Library of Congress Classification outline Classification - Cataloging and acquisitions. Retrieved from https://www.loc.gov/catdir/cpso/lcco/

Mai, J. E. (2016). Marginalization and exclusion: Unraveling systemic bias in classification. Knowledge Organization, 43(5), p. 324-530.

Olson, H. A. (2002). The power to name: Locating the limits of subject representation in libraries. Dordrecht, The Netherlands: Kluwer Academic Publishers.

Rofofsky, S. M. (2011). The changing terms in Sears. Judaica Librarianship, 16, p. 113-124. doi:10.14263/2330-2976.1007.

Ruderman, E. (2000). Library of Congress classification for Judaica: Recent changes (1995-1996). Judaica Librarianship, 10, p. 31-40. doi:10.14263/2330-2976.1151

Schoppert, A. (2014). A review of the literature on Elazar's classification system for libraries of Judaica. Cataloging and Classification Quarterly, 52(4), p. 422-430. doi:10.1080/01639374.2014.881448

Sperber Community Library. (2017). About us: Sperber Community Library. Retrieved from http://sperber.aju.edu/about-us/

Stahl, S., \& Kushner, J. (2014). Be-tselem Elohim--in the image of God: Identifying essential Jewish LGBTQ materials for Jewish libraries. Judaica Librarianship, 18(1), p. 15-53. doi:10.14263/2330-2976.1032

Tewell, E. (2016). Toward the resistant reading of information: Google, resistant spectatorship, and critical information literacy. Portal: Libraries \& The Academy, 16(2), p. 289-310.

Woodward, L. (2011). Running an English-language library for the literary disabled. The ANZTLA EJournal, (7), p. 113-117. 